\title{
Social Relationships, Prosocial Behaviour, and Perceived Social Support in Students From Boarding Schools
}

\section{Jens P. Pfeiffer', Martin Pinquart' ${ }^{\prime}$, and Kathrin Krick ${ }^{2}$}

\begin{abstract}
Social development may vary depending on contextual factors, such as attending a day school or a boarding school. The present study compares students from these school types with regard to the achievement of specific social goals, perceived social support, and reported prosocial behaviour. A sample of 701 students was examined. Students from boarding schools reported higher success in gaining autonomy from parents and forming romantic relationships than students from day schools. However, adolescents from day schools reported higher levels of peer-group integration than students from boarding schools. Compared with students from day schools, students from boarding schools perceived more support from their teachers, but less support from their parents. No difference in prosocial behaviour was found between the two groups. We conclude that some students from boarding schools need support in gaining access to a peer group. In addition, measures are suggested for promoting parental support of students from boarding schools.
\end{abstract}

\section{Keywords}

boarding school, residential school, developmental tasks, social support, prosocial behaviour

\section{Social Relationships in Students From Boarding Schools}

During adolescence, peers become increasingly important (e.g., Steinberg, 2014). This is reflected in some typical adolescent development goals, such as becoming independent from parents, connecting with a peer group, and forming close friendships and a

\footnotetext{
'Philipps University of Marburg, Germany

2University of Munich, Germany

\section{Corresponding Author:}

Jens P. Pfeiffer, Psychologist, Research Associate, Department of Child and Adolescent Psychiatry, Psychosomatics and Psychotherapy Faculty of Human Medicine, Philipps University Marburg,

Hans-Sachs-Str. 6, 35039 Marburg, Germany.

Email: jens.pfeiffer@uni-marburg.de
} 
romantic relationship (see Wenxin, Lingling, Lingin, \& Nurmi, 2006). According to the peer socialization theory by Harris (1995), peers are more important than parents for some aspects of personality development, such as developing group-related competence. When adolescents attend a boarding school, they are placed in a context where a lot of time is spent with peers.

Boarding schools provide a semi-permanent institution for education and living accommodation for students (Chang, 2011) and are mostly based on the Youth Protection Law (White, 2004). In Germany, there are approximately 240 boarding schools (Boarding School Finder, 2014). Boarding schools have different benefactors, such as registered associations (in the case of German "Rural School Halls of Residence"; RSHRs) or the Protestant and Catholic Church grounded in Christian attitudes. School fees for large proportions of students from some RSHRs are financed by Youth Welfare Offices because of their role in addressing a child's serious problems at home or in their previous school. However, such students can also be found in other kinds of boarding schools (Esser, 2006). In Germany, "elite" boarding schools are the exception. Different reasons may lead parents to send their children to boarding schools. In Western countries, the most known reasons are parental mobility (e.g., living abroad), problems in regular school placements or at home, and maintenance or improvement of social status (by sending children to prestigious schools; White, 2004). In contrast, some parents might send their children to a boarding school, because of large distance between their place of living and the location of schools.

Bronfenbrenner (1970) highlighted that development takes place in social contexts, which provide different opportunities for the achievement of development goals. The boarding school environment provides a particular ecological context in the socialization process that differs in some respects from the context of day schools. Boarding schools offer special facilities and activities such as sports facilities, library, cultural projects, or continuing education courses. Furthermore, adolescents from boarding schools spend more time with peers and less time with parents than adolescents from day schools do. Therefore, the comparison of adolescents from boarding schools and day schools provides interesting insights into the role of social contexts for adolescent development.

Very few studies have compared social relationships of adolescents from boarding schools and day schools (Little, Kohm, \& Thompson, 2005). Martin, Papworth, Ginns, and Liem (2014) showed that Australian students from boarding and day schools did not differ in the perception of their relationship with peers and teachers, but students from day schools reported a better relationship with their parents than students from day schools did. An Israeli study examined social relationships in terms of family climate and found no differences in the perception of family climate between students from boarding schools and day schools (Shulman \& Prechter, 1989). Furthermore, the study found some evidence for family-related risk factors (e.g., separation or divorce of parents) being more prevalent in students from boarding schools than in their peers from day schools. With regard to romantic/sexual relationships, some African studies showed that adolescents from boarding schools had less sexual experience than adolescents from day schools (Kenya: Kabiru \& Orpinas, 2009), and women from boarding schools had fewer sexual partners than women from day schools (Ghana: Afenyadu 
\& Goparaju, 2003). However, it is not clear whether these results could be generalized to other cultural contexts.

With regard to prosocial behaviour, Martin et al. (2014) found that students from boarding schools were more likely to be involved in prosocial activities, such as community service and volunteering, than students from day schools. In contrast, Australian students from boarding schools reported less prosocial behaviour than the total sample of students from different school types (Lester \& Cross, 2014; Lester \& Mander, 2015). Finally, studies from Spain (Garcia \& Monteoliva, 2000; Sanchez \& Martinez, 2001, 2007) found that adolescents from boarding schools showed less empathy and had more adjustment problems than adolescents from day schools.

Transitioning to and staying in a boarding school could be expected to have an impact on social relationships and psychosocial development in general: A boarding school may provide a greater variety of educational opportunities and often provides better care than a day school (Esser, 2006). However, living in a boarding school is also associated with separation from parents, former friends, and familiar surroundings. Contact with peers plays a particularly important role for adolescents at boarding schools, and teachers or educators assume a greater role in students' socialization compared with teachers from day schools (Bronfenbrenner, 1970; Martin et al., 2014). In addition, more stringent restrictions may be in place in boarding schools than in day schools, for example, regarding going out, cell phone use, or alcohol prohibitions (White, 2004), and there is less privacy in comparison with the parental home.

\section{Research Questions}

The present study focuses on aspects of social relationships of students from boarding schools and day schools, which have not been well examined until now. This comparison provides important insights in how variations in the availability of parents and peers may affect adolescent social development. In addition, the study provides knowledge on the role of teachers as sources of support if students do not have daily contact with their parents.

Boarding students spend more time with peers and less time with their parents than students from day schools do. This could promote the development of friendships and peer-group membership. Furthermore, they are separated from their parents during the school term, which could promote their development of autonomy. Therefore, the first research question asked whether students from boarding schools would report greater success in achieving the goals "gaining autonomy from parents," "belonging to a group of peers," "having a close friend," and "forming a romantic relationship" than students from day schools.

Students from boarding schools spend comparatively less time with their parents and more time with teachers and educators than students from day schools, which could affect the availability of support from these sources. Therefore, the second research question asked whether students from boarding schools perceive more social support from teachers and less social support from their parents in comparison with students from day schools.

Martin et al. (2014) found that students from boarding schools were more likely to be involved in prosocial activities, while Lester and Mander (2015) observed that 
students from boarding schools reported less prosocial behaviour than students from day schools. Given the inconsistent results of previous studies, we could not state a specific hypothesis with regard to group differences in prosocial behaviour. Thus, an undirected research question was formulated. The third research question asked whether German students from boarding schools and day schools report different levels of prosocial behaviour.

Finally, according to Bronfenbrenner (1970), more time spent with peers may provide more opportunities for achieving peer-related goals, and spending less time with parents could promote autonomy development. Therefore, the fourth research question asked whether students from boarding schools who spend their weekends with peers at dormitories show higher levels of success in achieving the goals "gaining autonomy from parents," "belonging to a group of peers," "having a close friend," and "forming a romantic relationship" than students from boarding schools who spend their weekends in their parental homes.

\section{Method}

\section{Participants}

The present study included 12- to 19-year-old students from nine German boarding schools and six day schools that were randomly chosen. All participants were students from the highest school track. The Ethics Committee of the German Psychological Society approved the study. After receiving permission from the school boards, parents, and adolescents, we asked the students to complete a questionnaire in their classes.

In total, 723 adolescents participated; 22 of them were excluded from the analyses because of being too young (11 years; $n=2$ ) or too old (20 years; $n=3$ ) or because information was missing on relevant study variables. For example, we did not include 11-year-old students because they might be too young for forming romantic relationships. The response rate was approximately $83 \%$. The final sample included 297 adolescents from boarding schools and 404 adolescents from day schools. The two groups of students differed in nearly all assessed socio-demographic variables (Table 1). Adolescents from boarding schools were, on average, older, more likely male, and their parents had more often completed the highest school track. Thus, we controlled for these variables in our analyses.

\section{Measures}

Social goals. To assess the attainment of social goals, we used items from the Development Task Questionnaire (DTQ) by Seiffge-Krenke (1998). Each participant was asked to assess his or her perceived current developmental states ("How far along are you in attaining this goal at this time?") on 3-point Likert-type scales ( $1=$ not yet started, 2 = still in progress, 3 = already finished). In the present study, we used the following social goals: autonomy from parents (be independent of my parents), peergroup integration (belong to a group of peers), close friendship (have a good friend 
Table I. Characteristics of the Sample and Test for Between-Group Differences in SocioDemographic Variables.

\begin{tabular}{|c|c|c|c|c|c|c|c|c|c|c|c|}
\hline & \multicolumn{3}{|c|}{$\begin{array}{l}\text { Total } \\
\text { sample }\end{array}$} & \multicolumn{3}{|c|}{$\begin{array}{l}\text { Adolescents } \\
\text { living with their } \\
\text { parents }\end{array}$} & \multicolumn{3}{|c|}{$\begin{array}{l}\text { Adolescents } \\
\text { living in boarding } \\
\text { schools }\end{array}$} & \multirow[b]{2}{*}{$F(I, 700)$} & \multirow[b]{2}{*}{$\eta^{2}$} \\
\hline & M & $S D$ & $\%$ & M & $S D$ & $\%$ & $M$ & $S D$ & $\%$ & & \\
\hline Age & $15.4 \mid$ & 1.87 & & 15.00 & 1.66 & & 15.98 & 2.00 & & $50.62 * * *$ & .07 \\
\hline Female gender & & & 46.6 & & & 55.4 & & & 34.7 & $30.80 * * *$ & .04 \\
\hline $\begin{array}{l}\text { Father's completion of } \\
\text { highest school track }\end{array}$ & & & 68.4 & & & 61.1 & & & 78.4 & 35.71 栦 & .05 \\
\hline $\begin{array}{l}\text { Mother's completion of } \\
\text { highest school track }\end{array}$ & & & 64.6 & & & 55.2 & & & 77.1 & $37.42 * * *$ & .05 \\
\hline$n$ & & 701 & & & 404 & & & 297 & & & \\
\hline
\end{tabular}

Note. $\eta^{2}=$ variance explained by group membership.

$* * * p<.001$.

with whom I can talk about almost anything), and romantic relationship (have a romantic relationship). Support for the concurrent validity of the items (e.g., correlations with related measures of the quality of friendship and romantic relationships) has been reported (Pinquart \& Pfeiffer, 2013).

Social support. We used a modified version of the subscales Perceived Emotional Support and Perceived Instrumental Support from the Berlin Social Support Scales (Schulz $\&$ Schwarzer, 2003). Six out of the eight items were asked with regard to support from peers, parents, and teachers. Answers were marked on a 4-point Likert-type scale ranging from 1 (totally wrong) to 4 (totally true). A sample item is, "Those people really like me." In the present study, internal consistency (coefficient alpha) was .91 for perceived parental support, .88 for teacher support, and .89 for peer support. Evidence for the predictive validity of this measure is provided by Schulz and Schwarzer (2003).

Prosocial behaviour. We applied the subscale prosocial behaviour of the Strengths and Difficulties Questionnaire (SDQ; Goodman, 2001). Positive attributes were assessed using five items referring to the past 6 months (with $0=$ not true, $1=$ somewhat true, 2 = certainly true). A sample item is, "I try to be nice to other people. I care about their feelings." In the present study, coefficient alpha was .63. The scale shows construct, concurrent, and predictive validity (e.g., Goodman, 2001; Malti, Gummerum, Keller, \& Buchmann, 2009).

Socio-demographic variables. These characteristics were assessed with single-item indicators: age (in years), gender $(0=$ male, $1=$ female $)$, habitation $(0=$ living with parents, 1 = living in boarding school), father's and mother's educational attainment $(0=$ did not completed highest school track, $1=$ completed highest school track $)$, parental divorce $(0=$ yes, $1=$ no $)$, and weekend accommodation $(0=$ at home, $1=$ at boarding school). 


\section{Results}

First, to test for between-group differences in the attainment of social goals, we used MANCOVA with boarding school as independent variable. Covariates were age, gender, and educational status of parents, and the dependent variables were the perceived attainment of the four assessed social goals (autonomy from parents, peer-group integration, close friendship, and romantic relationship).

We found a main effect of boarding school, $F(4,671)=10.73, p<.001, \eta^{2}=.06$. Students from boarding schools reported higher levels of success in gaining autonomy from parents and forming romantic relationships than students from day schools (Table 2). However, students from day schools perceived greater success in belonging to a peer group. No between-group difference was found with regard to close friendship. The effect sizes can be interpreted as small to very small (Cohen, 1992).

To analyse between-group differences in perceived support, we computed a second MANCOVA with the aforementioned independent and control variables. We used social support from peers, parents, and teachers as dependent variables. We found a main effect for boarding school, $F(3,684)=32.64, p<.001 ; \eta^{2}=.13$. Post hoc analysis showed between-group differences in support from parents and teachers, but no difference in support from peers. Students from boarding schools perceived less support from parents than students from day schools while the reverse was true with regard to support from teachers (Table 2). Nonetheless, as indicated by the non-overlap of the $95 \%$ confidence intervals, students from boarding schools, similar to those from day schools, perceived less support from their teachers than from their parents and peers (Table 2).

For prosocial behaviour, a univariate ANCOVA was computed with the aforementioned independent and control variables. We found no significant difference between the groups, $F(1,691)=.27, n s$; Table 2 .

Finally, we tested whether the perceived attainment of the four social goals in students from boarding schools differed between those who spend their weekends in the parental home and those who stay in boarding schools at the weekend. In the subsample of students from boarding schools, we calculated a MANCOVA with the independent variable weekend accommodation (with parents vs. at boarding school) and the covariates gender and educational status of parents, which differed between the two groups. Attainment of the social goals was used as the dependent variable. We found no main effect of the independent variable, $F(4,261)=1.68$, ns. Nonetheless, post hoc tests showed a significant difference in the field of close friendship, $F(1,264)$ $=3.09, p_{\text {one-tailed }}<.05 ; \eta^{2}=.01$. Students who stay in a boarding school at the weekend reported higher levels of success in developing close friendships than their classmates who spend the weekends at the parental home $\left(M_{\text {weekend stay }}=2.16\right.$ vs. $\left.M_{\text {home stay }}=2.05\right)$.

\section{Discussion}

The present study found that students from boarding schools perceived greater success in gaining autonomy from parents and forming romantic relationships than students from day schools. In contrast, adolescents from day schools reported higher levels of 
Table 2. Differences in Perceived Attainment of Goals and Social Support Between Adolescents From Boarding Schools and Day Schools.

\begin{tabular}{|c|c|c|c|c|c|c|}
\hline & $\begin{array}{l}\text { Adolescents } \\
\text { from boarding } \\
\text { schools (SD) }\end{array}$ & $95 \% \mathrm{Cl}$ & $\begin{array}{l}\text { Adolescents } \\
\text { from day } \\
\text { schools (SD) }\end{array}$ & $95 \% \mathrm{Cl}$ & $F(I, 678)$ & $\eta^{2}$ \\
\hline $\begin{array}{l}\text { Peer-group } \\
\text { integration }\end{array}$ & $2.70(.50)$ & {$[2.64,2.76]$} & $2.84(.50)$ & {$[2.79,2.89]$} & $12.13^{* * * *}$ & .02 \\
\hline $\begin{array}{l}\text { Autonomy from } \\
\text { parents }\end{array}$ & $2.14(.61)$ & {$[2.07,2.2 I]$} & $1.88(.60)$ & {$[1.82,1.94]$} & $28.52 * * *$ & .04 \\
\hline $\begin{array}{l}\text { Romantic } \\
\text { relationship }\end{array}$ & $2.04(.77)$ & {$[1.95,2.13]$} & $1.92(.92)$ & {$[1.84,2.00]$} & $3.90 *$ & .01 \\
\hline Close friendship & $2.76(.52)$ & {$[2.70,2.82]$} & $2.81(.62)$ & {$[2.76,2.86]$} & 1.26 & .00 \\
\hline $\begin{array}{l}\text { Social support from } \\
\text { parents }\end{array}$ & $3.49(.63)$ & {$[3.42,3.57]$} & $3.66(.62)$ & {$[3.60,3.73]$} & 11.57 **** & .02 \\
\hline $\begin{array}{l}\text { Social support from } \\
\text { teachers }\end{array}$ & $2.41(.72)$ & {$[2.32,2.49]$} & $1.93(.70)$ & {$[1.86,1.99]$} & $72.53 * * *$ & .10 \\
\hline $\begin{array}{l}\text { Social support from } \\
\text { peers }\end{array}$ & $3.54(.55)$ & {$[3.48,3.6 \mathrm{I}]$} & $3.60(.54)$ & {$[3.54,3.64]$} & 1.23 & .00 \\
\hline Prosocial behaviour & $2.47(.36)$ & {$[2.42,2.49]$} & $2.45(.36)$ & {$[2.43,2.5 \mathrm{I}]$} & 0.27 & .00 \\
\hline
\end{tabular}

Note. $95 \% \mathrm{Cl}=95 \%$ confidence interval of the mean; $\eta^{2}=$ variance explained by group membership. $*_{p}<.05 . * * * p<.001$.

success in gaining access to a peer group than adolescents from boarding schools. Compared with students from day schools, students from boarding schools perceived more social support from their teachers but less support from their parents. Perceptions of social support from peers and self-reports of prosocial behaviour did not differ between students from boarding schools and day schools. Finally, we found that students from boarding schools who stayed at school at weekends reported higher levels of success in forming close friendships than students from boarding schools who spent their weekends at the parental home. Although between-group differences in teacher support were of moderate size, other between-group differences tended to be small (Cohen, 1992).

The higher levels of success in gaining autonomy from parents and forming a romantic relationship reported by boarding school students were in line with our expectations, thus indicating that boarding schools may promote independence from parents and developing social relationships with peers. Nonetheless, we cannot rule out that between-group differences in autonomy may have already existed before students changed to a boarding school as young people who are highly dependent upon their parents may be less willing to attend a boarding school. Our findings regarding romantic relationships seem to contradict the results of African studies, where students from boarding schools reported fewer sexual experiences than students from day schools (Afenyadu \& Goparaju, 2003; Kabiru \& Orpinas, 2009). The differences between the studies may be, first, based on the use of different outcome variables as we assessed romantic relationships rather than sexual contacts. Second, Kabiru and 
Orpinas (2009) reported that - in contrast to the participating German boarding schools - many African boarding schools are not coeducational, which limits opportunities for forming romantic and sexual relationships. Finally, African boarding schools might be stricter with regard to romantic and/or sexual relationships than German boarding schools.

The observed lack of between-group difference in forming close friendships may be based on a ceiling effect as students from both kinds of schools reported high success rates. Previous studies have shown that it is easier to develop a close friendship than a romantic relationship or a peer group (Pfeiffer \& Pinquart, 2011).

Interestingly, adolescents from day schools reported higher levels of success with peer-group membership than adolescents from boarding schools. In principle, adolescents may gain access to peer groups with students from their school or with adolescents from outside their school. As students from boarding schools spend a lot of their spare time with other students from their school, they may have restricted opportunities for finding a peer group from outside if they do not gain access to peer groups within their school. This may be a particular problem for some students from boarding schools as students from boarding schools experience more relational victimization than students from day schools, such as being excluded from group activities (Pfeiffer \& Pinquart, 2014).

The observed lower levels of parental support of students from boarding schools as compared with day schools may be based on the lower availability of parents during the time spent at school and/or problematic family relationships, which might even have led to living in a boarding school in the first place (Handford, Mattison, Humphrey, \& McLaughlin, 1986). Although Martin et al. (2014) reported that students from boarding schools and day schools did not differ in the perception of the relationship with their teachers in general, the present study found much higher levels of perceived teacher support in students from boarding schools than in students from day schools. Although teachers may offer more support to students from boarding schools, this may not be sufficient to get along better with these teachers in general. Alternatively, the quality of the teacher-student relationships may have been better in the participating German boarding schools than in the Australian boarding schools assessed by Martin et al. (2014).

We did not find significant group differences in prosocial behaviour. As the results of previous studies were inconsistent (Garcia \& Monteoliva, 2000; Lester \& Mander, 2015; Martin et al., 2014; Sanchez \& Martinez, 2001, 2007), between-group differences may be found if one kind of school implements particular measures aimed at promoting prosocial behaviour, such as participation in voluntary community service (Martin et al., 2014), or if students with low levels of prosocial behaviour and high levels of antisocial behaviour are more likely to be sent to a boarding school (Sanchez $\&$ Martinez, 2001). The lack of between-group differences in prosocial behaviour may also have been caused by the low internal consistency of the SDQ subscale that has been used in the present study.

Finally, students from boarding schools who spend their weekends at home and those who stay in boarding school differed only with regard to perceived success in forming close friendships. Spending a lot of time with peers during the weekend provides more opportunities for developing friendships. In contrast, spending the 
weekend at boarding school may not be as beneficial for forming peer groups if large numbers of the potential peer-group members spend their weekends at the parental home. Furthermore, spending the weekend at boarding school may not promote success in forming romantic relationships, as these relationships were in any case not very widespread among younger participants of our study. Furthermore, the availability of telephone and Internet could have reduced the size of group differences, because electronic media help students from boarding schools maintain contact with their peers when they spend the weekend at the parental home.

\section{Limitations and Conclusion}

The present study has some limitations. First, results of our study may not be able to be generalized to other countries with other criteria for access to boarding schools. Second, we included only subjects from the highest school track that gives access to university after completing school. Nonetheless, this kind of boarding school is most common in Germany. Third, only adolescents' self-reported data were available. Nevertheless, there is empirical support for the validity of the measures (e.g., Goodman, 2001; Pinquart \& Pfeiffer, 2013; Schulz \& Schwarzer, 2003). Fourth, some additional aspects of social relationships were not assessed in the present study, such as attachment to parents or the quality of friendships and romantic relationships. Fifth, although we controlled for group differences in the most common socio-demographic variables, students from boarding schools and day schools may also have differed in other, more subtle variables that have not been assessed in the present study.

Despite these limitations, we can conclude from the present study that students from boarding schools and day schools differ in their social relationships, and that different school contexts are beneficial for developing and maintaining some kinds of social relationships and detrimental for other kinds. As students from boarding school reported more problems in gaining access to a peer group, they may benefit from measures aimed at developing peer groups such as increasing extracurricular group activities and cooperative learning within classes (Slavin, 1995). In addition, Van den Berg, Segers, and Cillessen (2011) showed that rearranging the classroom ecology (seating least liked students close together) promoted improvements in likeability in the most disliked students. Furthermore, although teachers from boarding schools should be aware that students perceive much higher levels of teacher support than students from regular schools, they should not overestimate their importance as a source of support: Students from boarding schools (still) perceived their parents and peers as more important sources of support than their teachers. Regarding perceived parental support, the present results indicate that parents of students from boarding schools could do more to develop and maintain supportive relationships with their children, such as increasing the number of visits to the boarding school and the number of weekends their children spend at the parental home, or communicating more frequently with their children.

Future studies are needed to investigate media use, for example, of skype and smartphones, in boarding schools to examine the opportunities and limitations of media use for promoting parental support of students from boarding schools. Furthermore, studies are needed to explore in detail the romantic relationships in 
boarding schools and how rules might affect contacts in general and sexual relationships in particular. Given some heterogeneous results across different countries, crosscultural studies are needed, aimed at identifying the reasons for these differences.

\section{Declaration of Conflicting Interests}

The author(s) declared no potential conflicts of interest with respect to the research, authorship, and/or publication of this article

\section{Funding}

The author(s) received no financial support for the research, authorship, and/or publication of this article.

\section{References}

Afenyadu, D., \& Goparaju, L. (2003). Adolescent sexual and reproductive health behavior in Dodowa, Ghana. Retrieved from http://pdf.usaid.gov/pdf_docs/Pnacu206.pdf

Boarding School Finder. (2014). Internate in Deutschland [Boarding schools in Germany]. Retrieved from http://www.boarding-school-finder.com/de/articles/boarding-in-/germany

Bronfenbrenner, U. (1970). Reaction to social pressure from adults versus peers among Soviet day school and boarding school pupils in the perspective of an American sample. Journal of Personality and Social Psychology, 15, 179-189.

Chang, A. (2011). Prep review: Boarding schools. North Charleston, SC: CreateSpace.

Cohen, J. (1992). A power primer. Psychological Bulletin, 112, 155-159.

Esser, B. (2006, September 13). Internate - Das zweite Zuhause [Boarding school-The second home]. Focus Online. Retrieved from http://www.focus.de/schule/schule/schulwahl/schulserie/internate/schulserie-teil-3_aid_24513.html

Garcia, J., \& Monteoliva, A. (2000). Estudio longitudinal sobre la influencia del tipo de residencia, familiar-escolar, en las transiciones de la escuela al trabajo [Longitudinal study on the influence of the type of residence, family home and boarding school in the transitions from school to work]. Revista de Psicología Social, 15, 357-367.

Goodman, R. (2001). Psychometric properties of the Strengths and Difficulties Questionnaire. Journal of the American Academy of Child \& Adolescent Psychiatry, 40, 1337-1345.

Handford, H., Mattison, R. E., Humphrey, F. J., \& McLaughlin, R. E. (1986). Depressive syndrome in children entering a residential school subsequent to parent death, divorce, or separation. Journal of the American Academy of Child Psychiatry, 25, 409-414.

Harris, J. R. (1995). Where is the child's environment? A group socialization theory of development. Psychological Review, 102, 458-489.

Kabiru, C. W., \& Orpinas, P. (2009). Factors associated with sexual activity among high-school students in Nairobi, Kenya. Journal of Adolescence, 32, 1023-1029.

Lester, L., \& Cross, D. (2014). Do emotional and behavioural difficulties in primary school predict adolescent victimisation trajectories? Emotional \& Behavioural Difficulties, 19, 356-370.

Lester, L. J., \& Mander, D. J. (2015). The role of social, emotional and mental wellbeing on bullying victimisation and perpetration of secondary school boarders. Journal of Psychologists and Counsellors in Schools, 25, 152-169.

Little, M., Kohm, A., \& Thompson, R. (2005). The impact of residential placement on child development: Research and policy implications. International Journal of Social Welfare, 14, 200-209.

Malti, T., Gummerum, M., Keller, M., \& Buchmann, M. (2009). Children's moral motivation, sympathy, and prosocial behavior. Child Development, 80, 442-460. 
Martin, A. J., Papworth, B., Ginns, P., \& Liem, G. A. D. (2014). Boarding school, academic motivation and engagement, and psychological well-being: A large-scale investigation. American Educational Research Journal, 51, 1007-1049.

Pfeiffer, J. P., \& Pinquart, M. (2011). Attainment of developmental tasks by adolescents with and without visual impairment. Journal of Visual Impairment \& Blindness, 105, 33-45.

Pfeiffer, J. P., \& Pinquart, M. (2014). Bullying in German boarding schools: A pilot study. School Psychology International, 35, 580-591.

Pinquart, M., \& Pfeiffer, J. P. (2013). Does visual impairment lead to lower or higher levels of success in solving developmental tasks? A longitudinal study. Journal of Developmental and Physical Disabilities, 25, 579-595.

Sanchez, A. M., \& Martinez, G. J. (2001). Individual and sociodemographic differences between adolescents living at home vs. living at a boarding school. Revista de Psicologia General y Aplicada, 54, 587-603.

Sanchez, A. M., \& Martinez, G. J. M. A. (2007). Differences in educational attainment and labor market outcomes reached by young people who have lived in two different environments: Family home or boarding school. Revista Mexicana de Psicologia, 24, 139-148.

Schulz, U., \& Schwarzer, R. (2003). Soziale Unterstützung bei der Krankheitsbewältigung: Die Berliner Social Support Skalen (BSSS) [Social support in coping with illness: The Berlin Social Support Scales (BSSS)]. Diagnostica, 49, 73-82.

Seiffge-Krenke, I. (1998). Chronic disease and perceived developmental progression in adolescence. Developmental Psychology, 34, 1073-1084.

Shulman, S., \& Prechter, E. (1989). Adolescent perception of family climate and adaptation to residential schooling. Journal of Youth and Adolescence, 18, 439-449.

Slavin, R. E. (1995). Cooperative learning: Theory, research, and practice (2nd ed.). Boston, MA: Allyn \& Bacon.

Steinberg, L. (2014). Age of opportunity: Lessons from the new science of adolescence. Boston, MA: Harcourt.

Van den Berg, Y., Segers, E., \& Cillessen, A. (2011). Changing peer perceptions and victimization through classroom arrangement: A field experiment. Journal of Abnormal Child Psychology, 40, 403-412.

Wenxin, Z., Lingling, Z., Lingin, J., \& Nurmi, J. E. (2006). Adolescents' future-oriented goals and concerns. Psychological Science, 29, 274-277.

White, M. A. (2004). An Australian co-education boarding school as a crucible for life: A humanistic sociological study of students' attitudes from their own memoirs (Unpublished dissertation). University of Adelaide, Australia.

\section{Author Biographies}

Jens P. Pfeiffer, $\mathrm{PhD}$, is a clinical psychologist in the Department of Child and Adolescent Psychiatry at the Philipps University Marburg. His primary research interest is in the area of psychosocial development of students from boarding schools and adolescent non-suicidal self-injury.

Martin Pinquart is a professor in the Department of Psychology at the Philipps University Marburg. His primary research interest is in the area of developmental regulation and development of children and adolescents with chronically physically illnesses.

Kathrin Krick is a clinical psychologist in the Department of Child and Adolescent Psychiatry and Psychotherapy, University of Munich. She is doing research in the area of coping with depressive symptoms in adolescence. 